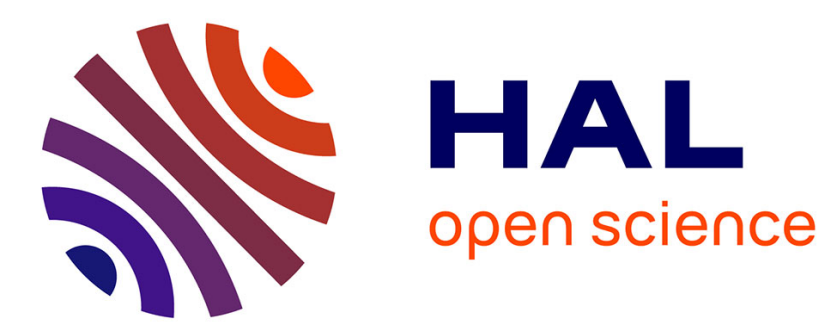

\title{
Lead 210 or climatic changes at South Pole?
}

\author{
J. Sanak, G. Lambert
}

\section{To cite this version:}

J. Sanak, G. Lambert. Lead 210 or climatic changes at South Pole?. Geophysical Research Letters, 1977, 4 (9), pp.357-359. 10.1029/GL004i009p00357 . hal-03408317

\section{HAL Id: hal-03408317 https://hal.science/hal-03408317}

Submitted on 29 Oct 2021

HAL is a multi-disciplinary open access archive for the deposit and dissemination of scientific research documents, whether they are published or not. The documents may come from teaching and research institutions in France or abroad, or from public or private research centers.
L'archive ouverte pluridisciplinaire HAL, est destinée au dépôt et à la diffusion de documents scientifiques de niveau recherche, publiés ou non, émanant des établissements d'enseignement et de recherche français ou étrangers, des laboratoires publics ou privés. 


\title{
LEAD 210 OR CLTMATIC CHANGES AT SOUTH POLE ?
}

\author{
J. Sanak and G. Lambert \\ Centre des Faibles Radioactivités, Laboratoire mixte CNRS-CEA \\ 91190 , Gif-sur-Yvette, France
}

Abstract. The ${ }^{210} \mathrm{~Pb}$ concentration has been measured in 92 adjacent firn samples collected at the South Pole along a $18 \mathrm{~m}$ depth profile. The decay analysis shows that significant changes happened around 1920 and 1954 either in the accumulation rate or in the ${ }^{210} \mathrm{~Pb}$ content of the new fallen snow.

\section{Introduction}

Using analyses based on the identification of seasonal or annual firn layers, as by variations in stable isotope ratios (Epstein et a1., 1965), or differences in physical structure (Giovinetto et al., 1966), or by the presence of fission products from specific nuclear explosions or test series (Crozaz et a1., 1964 ; Lambert et a1., 1975) snow accumulation rates at the South Pole have been found to be between 6 and $8.5 \mathrm{~cm}$ water per year for the interval 1955-1970.

An alternate means of determining this accumulation rate, first proposed by Goldberg (1962) is to measure the exponential decay with depth of the concentration in the firn of the 20 year half-life ${ }^{210} \mathrm{~Pb}$, assuming, as a basic hypothesis that this concentration is invariant in newfallen snow. This method has been applied by Crozaz et a1., (1964) who determined the ${ }^{210} \mathrm{~Pb}$ concentration of 8 discontinuous samples obtained at the South Pole at depths between 0 and 8 meters of water, and computed a mean accumulation rate of $6 \pm 1 \mathrm{~cm}$ water per year for the interval $1850-$ 1963 , in good agreement with the rates obtained using the first methods.

In this work we present the results of an exponential decay $v s$ depth analysis based on ${ }^{210} \mathrm{~Pb}$ concentrations determined for 92 adjacent firn samples collected at the South Pole.

$$
\text { Sampling }
$$

In December 1974, 23 adjacent, $10 \mathrm{~cm}$ thick samples were taken from the wall of a freshly dug, $4.8 \mathrm{~m}$ deep pit, and additional 69 samples, each about $18 \mathrm{~cm}$ thick, taken from a $12.5 \mathrm{~m}$ core drilled out subsequently in the bottom of the pit. The samples were collected with extreme care, packed in individual plastic bags, and returned frozen to the laboratory.

\section{Experimental details}

The concentrations of $210 \mathrm{~Pb}$ were determined by measuring the activity of its decay product $21{ }^{\circ} \mathrm{Po}$, which is an $\alpha$ emitter (half-life 138 days, $5.3 \mathrm{MeV})$. Details of the sample processing and apparatus are given elsewhere (Sanak, 1971). The background levels of the $\alpha$ spectrometers used were approximately 0.5 count per day in the peak

Copyright 1977 by the American Geophysical Union. and the absence of $21{ }^{\circ} \mathrm{Po}$ in the chemical solutions used was verified. Possible contamination of the samples (for instance, by atmospheric ${ }^{22} \mathrm{Rn}$ or ${ }^{210} \mathrm{~Pb}$ ) is unlikely owing to the extreme precautions taken, and confirmed by the trend of the results. The counting period used was that necessary to accumulate 400 counts and varied from a few days to 2 months depending on the depth of the sample. Counting errors ( $1 \sigma)$ were thus generally 4-5 percent for most samples, but approached 8-9 percent for a few of the deepest, least active samples where only about 200 counts were registered in the 2 months maximum counting period.

\section{Results}

The measured $21{ }^{\circ} \mathrm{Pb}$ concentrations are plotted vs depth (in meters of water) in figure 1. The exponential curve drawn represents the best least squares fit to the data and corresponds to an overall mean accumulation rate of $10.5 \pm 2 \mathrm{~cm}$ water/year, significantly higher than the values cited earlier. If this accumulation rate is assumed to be constant, a date can be assigned to the successive layers of firn and the initial concentration of ${ }^{210} \mathrm{~Pb}$ computed for each sample at the time of its deposition. This has been done in figure 2 in which the five sample running mean of the computed initial concentration is also plotted.

\section{Discussion}

It may be seen in figure 2 that, contrary to the basic hypothesis of the ${ }^{210} \mathrm{~Pb}$ method of data tion, the computed initial concentration of this

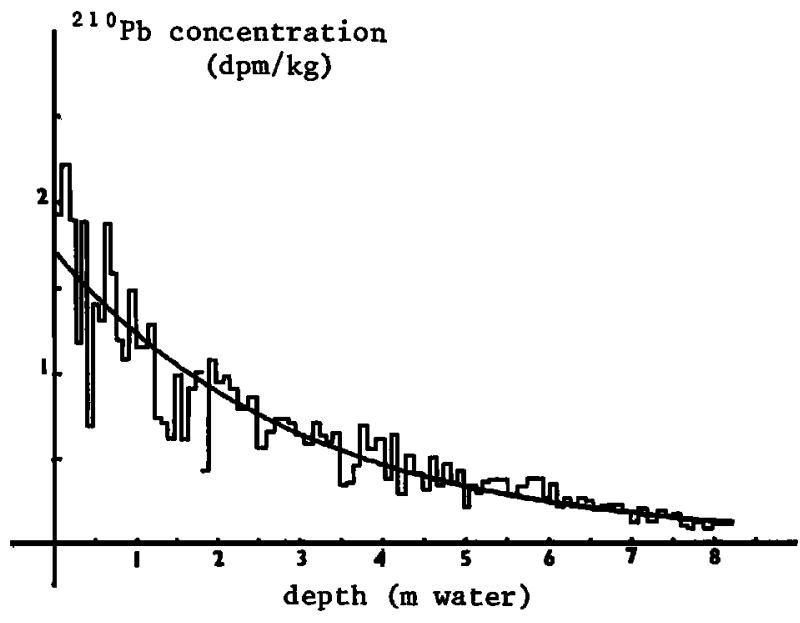

Fig.1. ${ }^{210} \mathrm{~Pb}$ concentration in the firn at the date of sampling vs depth. Accumulation rate : $10.5 \mathrm{~cm}$ water/year. 


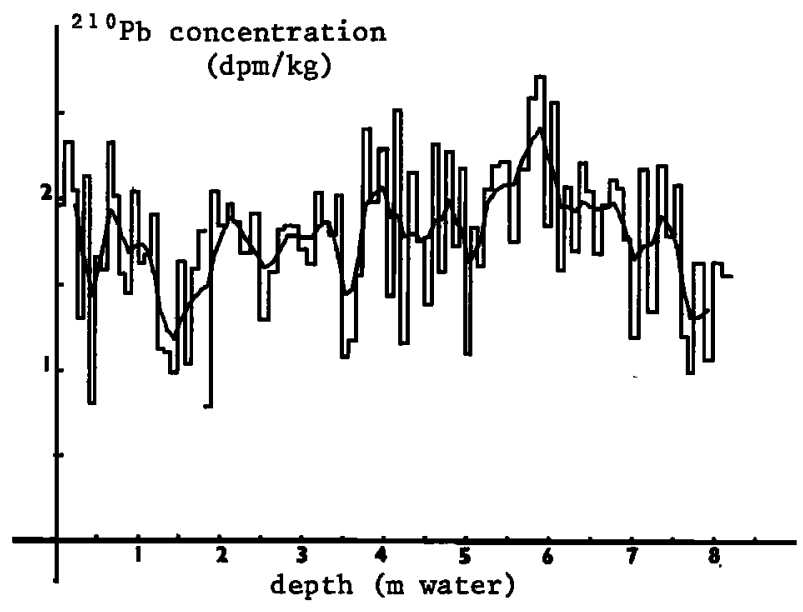

Fig.2. Computed 210 concentration in the firn at the date of the deposition of the snow vs depth assuming a mean accumulation rate of $10.5 \mathrm{~cm}$ water/year.

nuclide in the new fallen snow is not constant at all.

This concentration varies considerably from sample to sample as previously observed by Lambert et a1. (1971). Such fluctuations could reflect the variations in the atmospheric circulation of the ${ }^{210} \mathrm{~Pb}$ aerosols as well as the differences in the season deposition. A second point is that the running means vary with a depth constant of the order of 1 meter (corresponding to about 10 years). Because of these variations, the coefficient of the exponential decay of $210 \mathrm{~Pb}$ vs depth cannot be computed with good accuracy for a core shorter than several meters. Finally the calculated mean concentrations show a long term variation, first decreasing from the surface to about 1.5 meters depth, then increasing to about 6 meters depth and, finally decreasing to the bottom of the core at 8.21 meters.

On the basis of this information, it appears

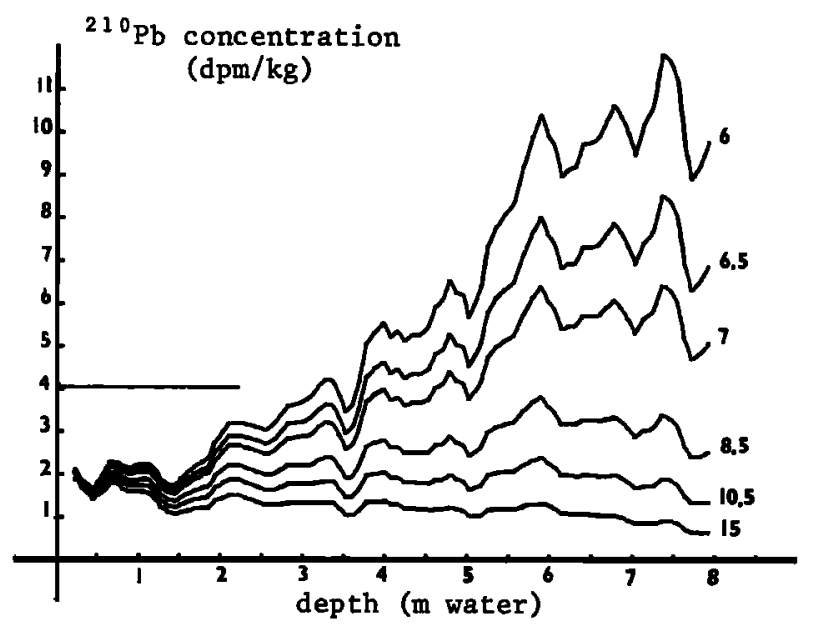

Fig.3 5 sample running means of the computed $2{ }^{0} \mathrm{~Pb}$ concentration in the fresh snow vs depth assuming different possible accumulation rates : $6,6.5,7,8.5,10.5$ and $15 \mathrm{~cm}$ water/year.

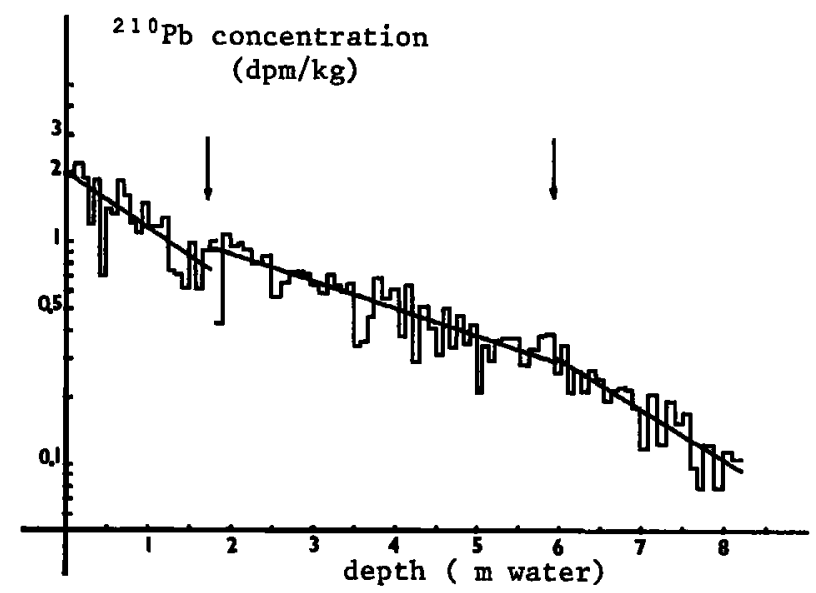

Fig.4 $21{ }^{\circ} \mathrm{Pb}$ concentration in the snow at the date of sampling vs depth. Computed accumulation rates : $6,12.5$ and $7 \mathrm{~cm}$ water/year.

unlikely that the initial assumptions of a cons tant rate of accumulation and constant initial $210 \mathrm{~Pb}$ concentration is correct.

We have tentatively calculated the initial $210 \mathrm{~Pb}$ concentrations in the fresh snow by using our data and different possible accumulation rates assumed as constant. Figure 3 shows the 5 sample running means of the concentration vs depth. Obviously the deepest samples are most affected by the accumulation rate choosen. It may be observed that an accumulation rate lower than $8 \mathrm{~cm}$ water/year would correspond to concentrations as high as $4 \mathrm{dpm} / \mathrm{kg}$ which seems inconsistent with the highest values ever measured in the superficial layers.

A new point of view could result from the observation of Fig. 4 where the original data are plotted using semi-log coordinates.

If the initial assumptions were correct, all the representative dashes should be situated along one mean straight line with a slope corresponding to a mean accumulation rate of 10.5 $\mathrm{cm}$ water/year. In fact 3 different regions can



Fig.5. Computed ${ }^{210} \mathrm{~Pb}$ concentration in the firn at the date of the deposition of the snow vs the date of the deposition assuming the 3 different and successive mean accumulation rates. 
be distinguished by their different slopes which correspond to the 3 long-term variations of concentration already mentioned. The simplest interpretation suggests the existence of 3 different regimes of accumulation :

- from the surface to $1.74 \mathrm{~m}$ depth the slope is consistent with an accumulation rate of the order of $6 \mathrm{~cm}$ water/year, but this determination is very inaccurate owing to the small thickness of the layer considered and a marked fluctuation of concentration observed. The rate of $8.5 \mathrm{~cm}$ water/year published by Lambert et al. (1975) for samples collected at the same place and time, on the basis of the fission products distribution, should be acceptable here and is probably a better evaluation,

- from 1.74 to $5.94 \mathrm{~m}$ depth, and then

- from this level to $8.21 \mathrm{~m}$ depth, the slopes are consistent respectively to accumulation rates of 12.5 and $7 \mathrm{~cm}$ water/year.

Figure 5 shows the initial concentrations of $210 \mathrm{~Pb}$ in the new fallen snow calculated by using these 3 different accumulation rates. As expected, the long-term variation of concentration is no longer seen.

\section{Conclusion}

There is no reason for assuming invariant the initial $210 \mathrm{~Pb}$ concentration in the fresh snow more than the accumulation rate. Thus the strong change of this rate suggested here is far from being considered as established. But, in any case, it is clear that something has changed at the South Pole between the levels 1.7 and 6 meters water, i.e. from 1954 to a year close to 1920 : the accumulation of the snow or its concentration in trace elements or more probably both.

It seems worthwhile to observe that Giovinetto and Schwerdtfeger (1966) have found a maximum of the accumulation rate precisely during this period, even though their figures are appreciably lower than ours.
Acknowledgments. The authors are very grateful to the group of $C$. Lorius for help in sampling at South Pole and thank M. Kritz for helpful discussions.

This work has been carried out thanks to the financial support of the Terres Australes et Antarctiques Françaises and the logistic support of the US Antarctic Research Program (Project S-33, 1974-1975).

\section{References}

Crozaz,G., Picciotto E., and de Breuck W., J. Geophys. Res., 69, (12), 2597-2604, 1964 Epstein,S., R.P. Sharp, and A.J. Gow, Six year record of oxygen and hydrogen isotope variations in South Pole firn, J. Geophys. Res., 79 , (8), 1809-1814, 1965.

Giovinetto,M.B., and W. Schwerdfeger, Analysis of a 200 year snow accumulation series from the South Pole, Arch. Meteor. Geophys. Bioklimato1., Ser. A, Band 15, 227, 1966.

Goldberg,E.D., Geochronology with lead 210, IAEA Conf., Athens, November 1962, 121-131.

Lambert,G., Le Roulley J.C., and Sanak J., Corrélation entre le dépôt de ${ }^{210} \mathrm{~Pb}$ dans 1 'Antarctique et les fluctuations du champ magnétique terrestre, C.R. Acad. Sc. Paris, $272,177-180,1971$.

Lambert, G., Ardouin B., Sanak J., Lorius C., and Brichet $\mathrm{E}$., Accumulation of snow and radioactive debris in Antarctic : a possible refined radiochronology beyond reference leve1s, Congr. Intern. UGGI, Grenoble, August 1975.

Sanak, J., Le ${ }^{210} \mathrm{~Pb}$ dans les aêrosols et les névés antarctiques ; application à l'étude des interactions soleil-basse atmosphère. Thèse 3ème Cycle, Paris 1971.

(Received June 1, 1977 accepted June 13, 1977.) 